Article

\title{
An Overview of the Utilisation of Brewery By-Products as Generated by British Craft Breweries
}

\author{
Clare Kerby and Frank Vriesekoop * \\ Department of Food Science and AgriFood Supply Chain Management, Harper Adams University, \\ Newport TF10 8NB, UK; 13089400@live.harper.ac.uk \\ * Correspondence: fvriesekoop@harper-adams.ac.uk, Tel.: +44-1952815241 \\ Academic Editor: Ombretta Maconi \\ Received: 1 April 2017; Accepted: 9 June 2017; Published: 12 June 2017
}

\begin{abstract}
There is a wide range of information available on by-product disposal methods used by large national breweries. However, little information is available on the methods of by-product disposal used by craft breweries. An investigation was carried out in which 200+ British craft brewers were contacted, of which 90 craft brewers provided basic information about their brewery operations and by-product disposal. Representatives of eleven breweries were interviewed to provide an in-depth case study of their by-product disposal methods. The research found that urban craft brewers use a wider range of disposal methods compared to rural craft brewers; urban brewers dispose of more waste through sewage and landfill, as well as using external companies, such as bio-recycling and anaerobic digester plants, whereas rural brewers have relationships with farmers who dispose of the by-products in various ways. Craft brewers tend to have a direct relationship with the by-product users. Even though they do not have all disposal options available to them which the large industrial breweries have, due to their small scale of by-product production, craft brewers appear to find alternative means of sustainability.
\end{abstract}

Keywords: spent grain; spent hops; hot trub; spent yeast; HACCP; disposal; urban; rural

\section{Introduction}

The brewing process produces various by-products, including: spent grain, spent yeast, and spent hops/hot trub [1]. The utilisation of high-volume brewery by-products as a valuable product stream within the business of larger breweries has been well-researched and applied to optimise environmental and economic sustainability [2]; however, little is known about the utilisation of brewery by-products among craft breweries. An extensive review of the literature has not been able to find any insight into waste disposal options and opportunities for the craft brewing industry in either Britain or any other country. The craft brewing industry in many countries has recently undergone a rapid expansion in the number of breweries and has gained market share from the larger (inter)national breweries [3]. It is likely that economies of scale preclude a very large portion of the craft brewing industry from the same economic benefits that larger breweries can demand when trading their excess by-products.

Landfill for solid wastes and disposal via sewage for liquid wastes are unsustainable and potentially expensive options. Most craft brewers will have adapted disposal options for their waste streams that are within their reach-financially and geographically. In order to fill the void in knowledge, this study presents, for the first time, empirical data to provide an insight into the range of waste disposal options that British craft brewers have explored over the years, and a dialogue with regards to real-life applications to produce a collage of options and opportunities that the wider craft brewing industry can utilize for their own optimization of waste disposal. 


\section{Background}

The concept of craft beer has been around since the 1970s, predominantly as a response to the perceived decrease in beer choice and quality. While a formal definition of craft beer has not been established in many countries, the concept often applies to microbreweries and brewpubs [3]. The craft brewing industry has seen expansion in numbers over the last few years. Despite the lack of a regulatory definition of craft beer, a craft brewer can be loosely defined as a small, independent brewer who uses traditional production methods [4].

Regardless of scale, the process of brewing beer unavoidably generates by-products and waste. Modern day brewing technological advances have been made to reduce the amount of waste produced and to generate useful materials from the by-products of brewing. There are economic advantages to reducing product waste and producing valuable by-products for the brewing industry [2]. The main by-products produced by the brewing process are: spent grain, spent yeast, and spent hops/hot trub.

\subsection{Spent Grain}

Spent grain is generated during the mashing process and is removed from the brewing process from the mash- or lauter tun or mash filter before the boiling step of brewing occurs. Spent brewers' grains are an abundant brewery by-product that is high in protein (more than $20 \%$ ) and fibre, which can be used as animal feed or, in some instances, spent grain can be used in foods for human consumption. With regards to animal feed, brewers' grains may be wet or dry in their final form for animal feed, with the wet grains typically being sold as cake for ruminant feeds, while dry spent grain is used for monogastric feeds. Brewers' spent grain provides the essential nitrogen-containing nutrients animals require in their feed [5]. Large breweries typically have their spent grain removed by animal feed producers who process the spent grain as a base material for animal feed, rather than having it delivered directly to farms. Spent grain offers an economic advantage to the animal feed market because it is a low-cost alternative to costly materials, such as soy bean. The nutritional and functional properties of spent grains have very comparable uses in human food as they do in animal feed $[5,6]$. Fărcaş et al. [6] reports that brewers' spent grain has desirable nutritional characteristics for the human diet. Although there has been no large-scale production of food products containing brewers' spent grain, there have been small-scale applications, such as using brewers' spent grain in high-fibre breads and cookies.

Another method used for the utilisation of brewers spent grain is composting. The composting of spent grain by itself has been found to be difficult because of its high moisture content [7]. Nevertheless, when combined with other waste streams, spent brewers grains can be successfully composted [8]. Energy production is another viable use for brewers spent grain. Energy generation can be conducted through direct combustion, or the production of biogas (methane) or bioethanol through fermentation [9]. Some larger breweries dispose of their spent grain through biogas production, either onsite or through a third-party energy producer. Biogas is typically produced in anaerobic digesters, which yield predominantly methane gas $[9,10]$. Using spent grain as a source of energy production will contribute towards making the brewing industry more sustainable by producing less waste and contributing to the value chain [5].

\subsection{Spent Hops/Hot Trub}

Spent hops or hot trub are most commonly removed from the brewing process as by-products from the wort production process, before fermentation occurs, however, hops can be added and removed from the beer-making process at various points. According to Huige [2], approximately $85 \%$ of hop material added to beer will become a by-product and require disposal. O'Rourke [11] has explored how spent hops are utilised from the UK brewing industry and found that the main methods of disposal are to reuse them as fertiliser or compost. The residual bitterness of spent hops makes it nearly impossible for it to be used as an animal feed. Spent hops have been trialled as a 
source of essential oils which can act as an insect repellent [12]. Compared with spent grain, spent hops have a higher fibre content. However, the energy that animals can gain from spent hops as feed compared to that of spent grain as animal feed is $50 \%$ less. Some brewers add their spent hops to their spent grain for disposal, however this is considered to compromise the sensory quality with many animals rejecting the feed. On the other hand, this method is much more convenient for breweries who produce smaller volumes [2].

\subsection{Spent Yeast}

During the fermentation process, yeast cells can multiply numerous times, which results in a markedly greater yeast mass than what is added at the commencement of a fermentation. The fermentation conditions of each brewery influence the yeast growth rate. Huige [2] claims that the typical volume of spent yeast collected from a lager fermentation is approximately $0.6-0.8 \mathrm{lb} / \mathrm{bbl}$ of the final volume of beer produced.

Similarly to spent grain, some breweries sell their spent yeast as animal feed as a source of protein and water-soluble vitamins [13]. Various trials have been published which examine the use of brewers' spent yeast as a feed supplement in diets for ruminants, horses, poultry, swine, and fish [5,13-18].

Spent yeast also takes up a significant position in human nutrition due to its high nutritional benefits. Well-known brands of yeast spreads are produced with spent brewers' yeast in numerous countries, although these products use extracts of yeast as it is uncommon to use whole brewers' spent yeast in human food applications. Yeast extracts are also used in food manufacturing to provide flavour $[19,20]$. Furthermore, the use of spent yeast for their potential as a source of minerals and B-complex vitamins, and high quantities of essential amino acids might provide additional opportunities to the brewing industry in terms of sustainability [21].

\subsection{Feed Hygiene Regulations}

In order to ensure food safety in the feed/food supply chain and be able to utilise food waste products as either feed or food ingredients, the European Union has implemented specific regulations that impact the by-products from any food production process, including those from the brewing process (re)entering the food chain, either directly or via animal feed. Regulation (EC) No. 183/2005 requires businesses who deal with animal feed intended for the food chain to register with their local authority and implement a dedicated HACCP plan, which includes the requirement for traceability. Brewers are required to register if they carry out the activity of selling brewery co-products (malt dust, spent brewers' grains, trub and spent hops, spent yeast (live or killed), and surplus beer) as feed materials [22]. The British Brewing, Food, and Beverage Industry Suppliers Association (BFBI) developed an assurance scheme in 2006 which is designed to assist small independent breweries with satisfying the requirements from farm assurance bodies. These requirements are to ensure the safety of the feed provided and that they are nutritious and safe [23]. To ensure the safety of by-products, HACCP assessments must be carried out. Some breweries add ammonium tetraformate to their spent yeast and grain to kill any microorganisms [24] and prevent the growth of mycotoxin-producing fungi [24]. Ammonium tetraformate is a potent preservative for animal feed [25], with no adverse effect on feeding efficiency on animals [26,27]. However, Lynch et al. [28] clarify that there are currently no regulations with the preservation of brewers' spent grain for applications in human food, but various countries have guidelines for best practice preservation for spent grain used for animal feed.

\section{Methods}

This study was carried out in two stages. The first stage was a quantitative survey carried out through an online questionnaire distributed to a range of British craft breweries of various sizes, in both rural and urban locations from London, the Midlands, and the northwest of England, which yielded 90 responses. In the online questionnaire, the responding breweries were asked to indicate their location by providing the first half of the brewery's postcode, the size of a typical batch that can 
be brewed, an estimate of annual production volume, and the year the brewery started production. All responding breweries were then asked to indicate how they disposed of their spent grain, spent yeast, and spent hops from a list of options provided. At the end of the questionnaire the brewery's responder was asked if they were willing to participate in a more detailed follow-up interview-based study. Approximately $50 \%$ of the responding breweries indicated that they were willing to participate in the interviews. A small selection of the brewers who indicated their willingness to participate were interviewed either in person, or over the phone (whichever format was most convenient for the brewer). The nine breweries who participated in the interviews were selected because of the answers they provided in the questionnaire; they either used unique methods or gave detailed answers which could be explored further. The interviews were structured and focused on specific attributes that were indicated in the online questionnaire. During the structured interviews the brewers were asked how they established the relationship with the third-party distributor they used, as well as why they used the chosen method and if they had ever used a different disposal method than the one they indicated. Additional questions were added which were tailored to the brewery and their responses given to the questionnaire.

\section{Results}

The work was carried out across the central area of England, with a relatively even distribution of small, medium-sized, and larger craft breweries throughout both various urban and rural areas in England (Figure 1). Forty of the craft breweries were located in urban areas, compared to $50 \mathrm{craft}$ breweries from rural areas. There was a high distribution of smaller craft breweries $(<1000 \mathrm{~L})$ located around London. In total this study entailed nine small-, 19 medium-, and 12 large-sized urban-located craft breweries; and 10 small-, 20 medium-, and 20 large-sized rurally-located craft breweries.

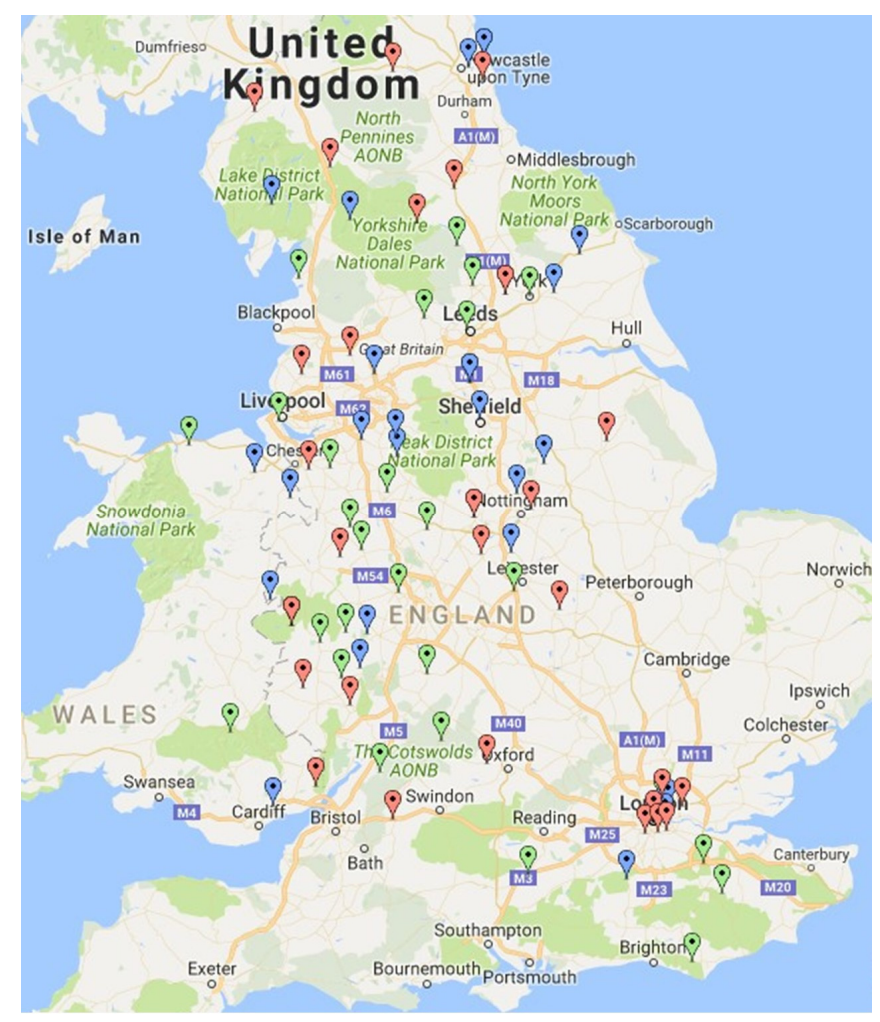

Figure 1. Geographical distribution of respondent craft breweries. Red tabs: craft breweries with a single batch capacity $<1000 \mathrm{~L}$; blue tabs: craft breweries with a single batch capacity $>1000 \mathrm{~L}$ and $<2000 \mathrm{~L}$; and green tabs: craft breweries with a single batch capacity $>2000 \mathrm{~L}$. The graph was generated from BatchGeo.com. 
The questionnaire produced results which gives an insight into UK craft breweries and their by-product disposal systems. To allow for a comparison based on the general location of the breweries, they were categorised into urban and rural according to their postcode. There was a relatively even distribution of brewers from urban and rural locations (Figure 2).

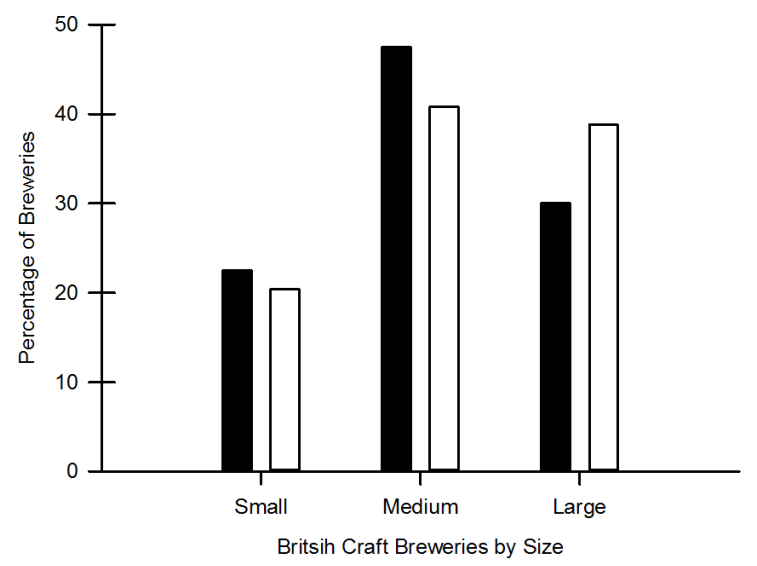

Figure 2. Brewery size distribution. Black bars: Urban-based craft brewers; white bars: Rural-based craft breweries. Small craft breweries having a batch capacity smaller than $1000 \mathrm{~L}$; medium-sized craft breweries having a batch capacity greater than $1000 \mathrm{~L}$, but smaller than $2000 \mathrm{~L}$; and large craft breweries having a batch capacity greater than $2000 \mathrm{~L}$.

\subsection{Spent Brewer's Grain}

Regardless of their location or size, the main method of grain disposal is animal feed (Figure 3). All rural-based craft breweries disposed of their spent grain as animal feed, and so did the larger urban-based craft breweries. However, the medium- and small-sized, urban-based craft breweries found alternative routes of spent grain disposal. The smaller craft breweries opted to have their spent grain being used to produce compost or directly as fertiliser as a sustainable disposal of the spent grains. However, some very small craft breweries had to dispose of their spent grain as landfill waste.
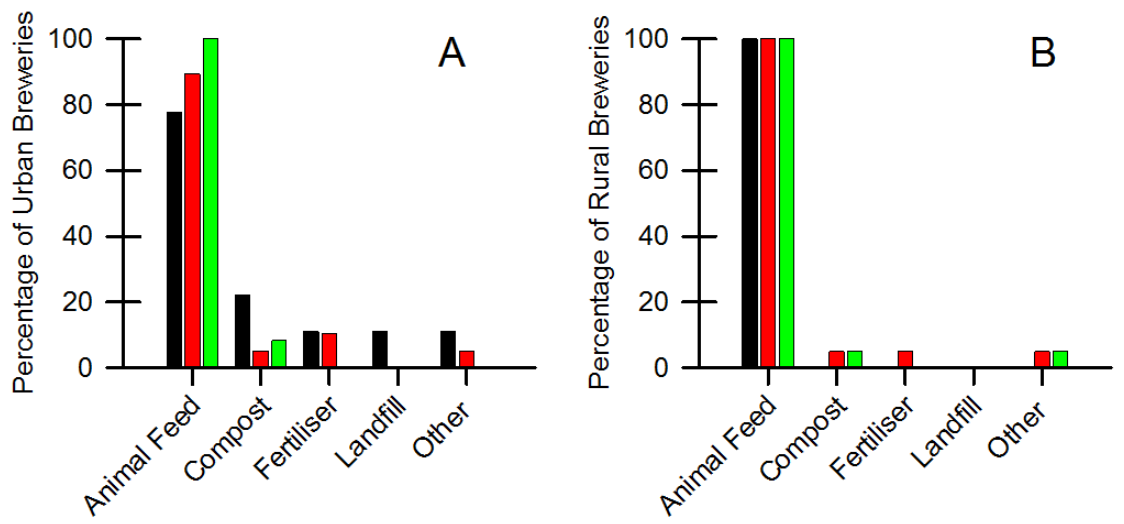

Figure 3. Spent grain disposal method in urban and rural based craft breweries. (A) Urban-based craft brewers; (B) rural-based craft breweries. Black bars: breweries with a batch capacity smaller than 1000 L; red bars: breweries with a batch capacity greater than 1000 L, but smaller than $2000 \mathrm{~L}$; and green bars: breweries with a batch capacity greater than $2000 \mathrm{~L}$. Total figures might add up to over $100 \%$ because some breweries employ multiple methods of disposal.

Two-thirds of small urban craft breweries have their spent grain removed from their site on a weekly basis, while the most common disposal frequency for medium-sized and large urban craft 
breweries was a couple of times per week, at $52.6 \%$ and $75 \%$ respectively (Table 1). A greater proportion of the larger rural-based craft breweries had their spent grain removed on a daily basis compared to the small rural-based craft breweries ( $42.1 \%$ vs. $20 \%$ respectively). On the other hand, $50 \%$ of the small rural-based craft breweries had their spent grain removed 2-3 times a week compared to $31.6 \%$ of the large rural-based breweries. A small number of breweries had no set pattern with regards to their spent grain removal, instead the spent grain was removed on the day or after the day of brewing.

Table 1. Frequency of spent grain removal and costs incurred, by brewery location and size.

\begin{tabular}{ccccccccc}
\hline \multirow{2}{*}{$\begin{array}{c}\text { Brewery; } \\
\begin{array}{c}\text { Location \& } \\
\text { Size }\end{array}\end{array}$} & \multicolumn{3}{c}{$\begin{array}{c}\text { Frequency of Spent Grain Removal from } \\
\text { Brewery Site }\end{array}$} & \multicolumn{3}{c}{$\begin{array}{c}\text { Cost Involved in Removal of Spent Grain } \\
\text { from Brewery Site }\end{array}$} \\
\cline { 2 - 9 } & Daily & 2-3/Week & Weekly & $\begin{array}{c}\text { When } \\
\text { Required }\end{array}$ & $\begin{array}{c}\text { Brewery } \\
\text { Incurs } \\
\text { No Cost }\end{array}$ & $\begin{array}{c}\text { Brewery } \\
\text { Facilitates } \\
\text { Disposal }\end{array}$ & $\begin{array}{c}\text { Brewery } \\
\text { Incurs } \\
\text { All Costs }\end{array}$ & $\begin{array}{c}\text { Brewery } \\
\text { Receives } \\
\text { Payment }\end{array}$ \\
\hline Urban-S & $11.1 \%$ & $11.1 \%$ & $66.7 \%$ & $11.1 \%$ & $55.6 \%$ & $44.4 \%$ & $0.0 \%$ & $0.0 \%$ \\
Urban-M & $15.8 \%$ & $52.6 \%$ & $26.3 \%$ & $5.3 \%$ & $89.5 \%$ & $10.5 \%$ & $0.0 \%$ & $0.0 \%$ \\
Urban-L & $25.0 \%$ & $75.0 \%$ & $0.0 \%$ & $0.0 \%$ & $75.0 \%$ & $0.0 \%$ & $0.0 \%$ & $25.0 \%$ \\
Rural-S & $20.0 \%$ & $50.0 \%$ & $20.0 \%$ & $10.0 \%$ & $70.0 \%$ & $20.0 \%$ & $0.0 \%$ & $10.0 \%$ \\
Rural-M & $25.0 \%$ & $40.0 \%$ & $35.0 \%$ & $0.0 \%$ & $90.0 \%$ & $5.0 \%$ & $0.0 \%$ & $5.0 \%$ \\
Rural-L & $42.1 \%$ & $31.6 \%$ & $26.3 \%$ & $0.0 \%$ & $73.7 \%$ & $10.5 \%$ & $0.0 \%$ & $5.2 \%$ \\
\hline
\end{tabular}

Regardless of their location, the vast majority of craft brewers incurred no cost for the disposal of spent grain from their site (Table 1). However, on occasion, both the urban and rural small craft brewers faciliated the removal of the spent grain themselves where the costs incurred were man-hours and fuel. Some of the rural-based breweries received payments for their spent grain, a trend only seen among the larger urban breweries.

The brewer from a typical, small urban craft brewery (Brewery US1) was interviewed with regards to their spent grain disposal method. Their spent grain is re-used as animal feed by a farmer. The farmer comes to the brewery and collects their spent grain once a week. The relationship between the brewery and the farmer was originally established with the farmer by a large national brewery who was present on the same site before Brewery US1 was established because the farmer used to collect malt dust from the mill screeners. Once Brewery US1 commenced production on their current site they "asked him if he wanted to utilise the spent grain because we do not produce big enough volumes to use the previous disposal method used by the national brewer" (quote brewer US1, 2017). Brewery US1 has a dedicated HACCP plan in place with regards to regulation EC:183/2005 because the spent grain goes back into the food chain. However, Brewery US1 is not a member of any assurance schemes, such as the one provided by BFBI.

The brewer from a medium-sized urban craft brewery (Brewery UM2) was interviewed with regards to their spent grain disposal method because they use a unique disposal method. Their spent grain is disposed of by a local anaerobic digester plant to produce biogas. The relationship between Brewery UM2 and the company operating the anaerobic digester was established when the brewery concluded that "using an anaerobic digester was the most efficient way to dispose of their spent grain" (quote brewer UM2, 2017) and a brewery representative contacted the plant direct. The anaerobic digester plant is approximately $15 \mathrm{~m}$ from the brewery and the only cost the brewery encounters is the transportation of the spent grain from the brewery to the plant. Brewery UM2 has no dedicated HACCP plan in place with regards to regulation EC:183/2005 and is not a member of an assurance scheme because their by-products do not re-enter the food chain.

The brewer from a medium-sized rural craft brewery (Brewery RM3) was interviewed with regards to their spent grain disposal method. The spent grain from Brewery RM3 is re-used as animal feed by a local farmer who is located approximately $5 \mathrm{~m}$ from the brewery. The relationship with the farmer is a historical relationship through local acquaintance. Brewery RM3 has a dedicated HACCP plan in place but are not a member of an assurance scheme because "it costs money for no 
return" (quote brewer RM3, 2017). Despite not being a member of an assurance scheme, their grain has been tested several times for toxins by local trading standards. Similarly, the brewer from another medium-sized rural craft brewery (Brewery RM4) was interviewed with regards to the disposal of their spent grain because they supply a local bakery with their spent grain. The local bakery contacted the brewery about potentially using spent grain from Brewery RM4 in their bread. Prior to supplying the bakery with their spent grain, the brewery disposed of their spent grain as animal feed. An understanding established that the bakery is responsible for the legal requirements of spent grain entering the food chain. Although brewery RM4 does have a HACCP plan in place under regulation EC:183/2005 and is a member of an assurance scheme.

A representative from a large rural craft brewery (Brewery RL5) was interviewed with regards to their unique and integrated method of spent grain disposal. Their spent grain is used as animal feed by a local pig farmer. They use this method as a unique marketing tool because they use a high-profile local farm who uses the spent grain to feed their pigs; these pigs are then used to provide pork for the brewery's tap house. Customers visiting the brewery and/or the tap house are offered pulled-pork rolls from pigs fed on the spent grain that came from the brewery. Essentially, the spent grain goes in a cycle back to the brewery enabling them to sell their story as "a local craft brewer who collaborates with a local farm business in a locally sustainable manner" (quote brewer RL5, 2017), where the story is personably relatable. Brewery RL5 has a dedicated HACCP plan in place under regulation EC:183/2005 and the company is a member of the assurance scheme provided by BFBI.

A large rural-based craft brewery (RL6) stood out because of their collaborative approach to spent grain disposal. Their spent grain is used as animal feed by a farmer, who collects the spent grain on a weekly basis. The relationship with the farmer is a historical relationship through local acquaintances. The collaboration with the smaller brewery is also through local acquaintances and it allows the smaller brewer to dispose of their spent grain in a sustainable manner, because, by themselves, the smaller craft brewery would not produce sufficient volumes of spent grain to engage directly with a farmer to take their spent grain. Brewery RL6 and the small brewery they collaborate with both have a dedicated EC:183/2005-HACCP plan in place, however, only the larger brewer is a member of the assurance scheme provided by BFBI.

\subsection{Spent Brewer's Yeast}

While most breweries with sufficient production frequency re-use some of their relatively fresh yeast to inoculate the next batch of wort, the vast majority of surplus yeast was treated as spent yeast. The most common disposal method for spent yeast by both rural and urban craft breweries is via their sewage system (Figure 4). However, the use of yeast disposal through the sewage is more prevalent among the smaller rural and urban craft breweries, and decreases in prevalence with increasing batch volume sizes. While some small urban craft breweries dispose of their spent yeast as an animal feed source, this disposal method is more frequently employed by medium-sized and larger rural craft breweries (approximately 20\% each) (Figure 4B). Both rural and urban craft breweries dispose of their spent yeast for composting purposes; while direct use as fertiliser is common among the urban craft breweries (Figure 4A). A small number of small and medium-sized, urban and rural craft breweries mix their spent yeast with the spent grain before it is carted off to a farmer, and in one instance for use as mixed substrate in an anaerobic digester. One large urban craft brewer disposed of its surplus yeast by selling it to a distillery as the inoculum for their fermentation; while two urban breweries had their spent yeast collected by commercial trade waste companies.

The vast majority of craft brewers disposed of their spent yeast within a couple of days of the yeast becoming surplus to their own needs, regardless of the location or batch capacity. However, regardless of location the small craft brewers tend to dispose of their spent yeast daily, and the larger the brewery becomes the less likely it is that the brewery disposes of their spent yeast immediately (Table 2). Some brewers store their spent yeast in a dedicated tank and the yeast is collected until the tank is sufficiently filled and is emptied when required. In one instance the rural craft brewer indicated 
that the spent yeast is collected in a tank, which (when emptied) is sprayed onto fields as fertiliser. Similar to the frequency of spent yeast disposal, regardless of the location, the small craft brewers are less likely to incur any costs with regards to spent yeast disposal; while the larger the brewery's batch capacity is, the more likely it is that the brewery pays some or all the costs of spent yeast disposal. Only two large urban-based craft brewers received payment for their spent yeast (Table 2).
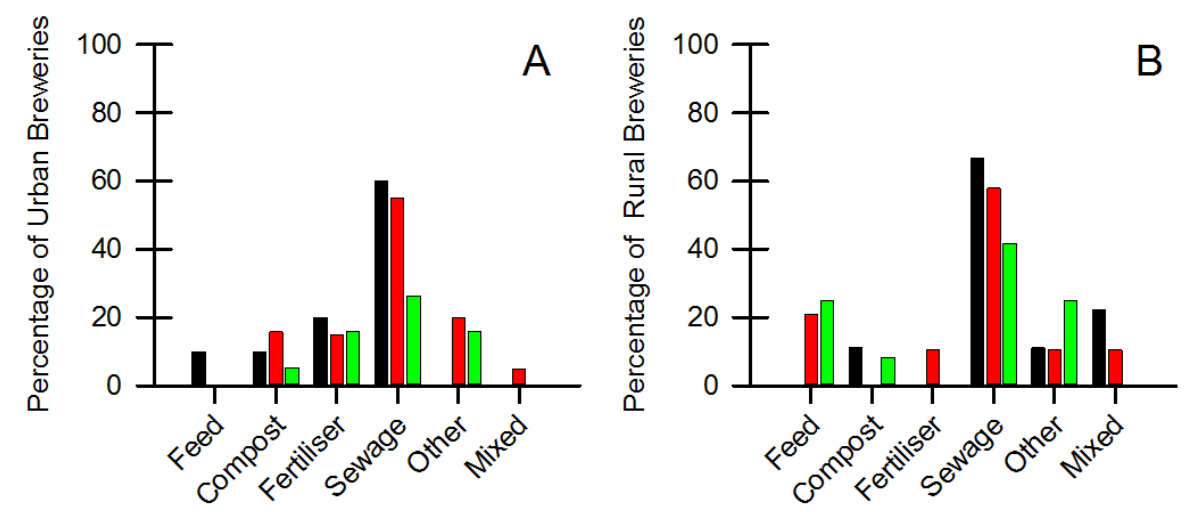

Figure 4. Spent yeast disposal method in urban and rural based craft breweries. (A) Urban-based craft brewers; (B) Rural-based craft breweries. Black bars: breweries with a batch capacity smaller than 1000 L; red bars: breweries with a batch capacity greater than $1000 \mathrm{~L}$, but smaller than $2000 \mathrm{~L}$; and green bars: breweries with a batch capacity greater than $2000 \mathrm{~L}$. Total figures might add up to over $100 \%$ because some breweries employ multiple methods of disposal.

Table 2. Frequency of spent yeast removal and costs incurred, by brewery location and size.

\begin{tabular}{ccccccccc}
\hline \multirow{2}{*}{$\begin{array}{c}\text { Brewery: } \\
\text { Location \& } \\
\text { Size }\end{array}$} & \multicolumn{2}{c}{$\begin{array}{c}\text { Frequency of Spent Yeast Removal from } \\
\text { Brewery Site }\end{array}$} & \multicolumn{3}{c}{$\begin{array}{c}\text { Cost Involved in Removal of Spent Yeast } \\
\text { from Brewery Site }\end{array}$} \\
\cline { 2 - 9 } & Daily & 2-3/Week & Weekly & $\begin{array}{c}\text { When } \\
\text { Required }\end{array}$ & $\begin{array}{c}\text { Brewery } \\
\text { Incurs } \\
\text { No Cost }\end{array}$ & $\begin{array}{c}\text { Brewery } \\
\text { Facilitates } \\
\text { Disposal }\end{array}$ & $\begin{array}{c}\text { Brewery } \\
\text { Incurs } \\
\text { All Costs }\end{array}$ & $\begin{array}{c}\text { Brewery } \\
\text { Receives } \\
\text { Payment }\end{array}$ \\
\hline Urban-S & $55.6 \%$ & $11.1 \%$ & $22.2 \%$ & $11.1 \%$ & $77.8 \%$ & $11.1 \%$ & $11.1 \%$ & $0.0 \%$ \\
Urban-M & $21.0 \%$ & $57.9 \%$ & $15.8 \%$ & $5.3 \%$ & $57.9 \%$ & $10.5 \%$ & $31.6 \%$ & $0.0 \%$ \\
Urban-L & $16.7 \%$ & $25.0 \%$ & $8.3 \%$ & $50.0 \%$ & $50.0 \%$ & $16.7 \%$ & $16.7 \%$ & $16.7 \%$ \\
Rural-S & $50.0 \%$ & $40.0 \%$ & $10.0 \%$ & $0.0 \%$ & $80.0 \%$ & $10.0 \%$ & $10.0 \%$ & $0.0 \%$ \\
Rural-M & $35.0 \%$ & $20.0 \%$ & $40.0 \%$ & $5.0 \%$ & $75.0 \%$ & $10.0 \%$ & $15.0 \%$ & $0.0 \%$ \\
Rural-L & $26.3 \%$ & $42.1 \%$ & $15.8 \%$ & $15.8 \%$ & $52.6 \%$ & $10.5 \%$ & $36.8 \%$ & $0.0 \%$ \\
\hline
\end{tabular}

The brewer from a small rural craft brewery (Brewery RS7) was interviewed with regards to their spent yeast disposal via the sewage system. Brewery RS7 expressed that they used the sewage system to dispose of the spent yeast because they "do not brew often enough at the correct gravity to maintain a yeast culture, so we do not collect the yeast" (quote brewery RS7, 2017). They explained that their water provider has been informed that this is their disposal method and that they are happy with the brewery using this method and their water rates have not been affected. The medium-sized, rural-based brewery (RM3) disposes of their spent yeast by means of the sewage system. During an interview the brewer from brewery RM3 stated that "the big breweries in our location send their spent yeast to the Marmite factory", and subsequently indicated that they did not produce enough spent yeast to use this method of spent yeast disposal. Brewery RM3 holds a permit from their water supplier to dispose of their yeast in this manner.

The brewer from a large rural craft brewery (Brewery RL8) was interviewed with regards to their unique disposal method for both their spent grain and spent yeast. Currently, both their spent grain and spent yeast are disposed of through a local farmer who has installed an anaerobic digester plant. The relationship was established with the farmer from the start of the brewery's production, 
when the farmer collected the spent grain from brewery RL8 for animal feed. Since the installation of an anaerobic digester by the famer, the famer has been taken both the spent grain and spent yeast. The brewer (RL8) stated that "being a rural business disposing of spent grain and spent yeast using an anaerobic digester plant is the most efficient method". The brewery maintains a dedicated EC:183/2005-HACCP plan and are a member of the assurance scheme provided by BFBI even though they have now changed their disposal method from animal feed to substrate for an anaerobic digester.

Two large craft brewers (one urban and one rural) discharged their yeast effluent in ponds. The urban-based craft brewer stated that they used anaerobic ponds; while the rural craft brewer operated a series of reed beds. The rural brewer (RL9) explained that this option of disposal is used because of their isolated rural location and that the brewery received a grant to setup the reed beds. Since the reed beds were installed the brewery has markedly increased its production volumes. The brewery's representative stated that to cope with increased volumes they had to "increase the size of the swell dish and add another pond, we also installed a compressor in the last pond to increase the oxygen levels before the reed bed run-off entered a natural water source so to ensure that the native aquatic live was not affected by the influx of oxygen depleted water" (quote: brewery RL9, 2017). In order to use this method brewer RL9 communicated with their water authority and gained their consent.

\subsection{Spent Brewer's Hops/Hot Trub}

The most common disposal method for spent hops is for fertiliser, however in comparison to the other by-products spent hops/trub shows a larger distribution of methods used by breweries (Figure 5). Even so, none of the craft brewers specifically disposed of their spent hops/trub for animal feed. However, spent hops/trub is frequently mixed with other spent material, usually with spent grain. Even though hops add a strongly bitter taste to the feed which reduces the feed quality [29]. Some brewers indicated that their spent hops are bagged up and made available for whoever was interested in taking it. Taken spent hops from craft breweries appeared a popular means for allotment gardeners to enrich their soils, either as compost or as 'green soil conditioner'.
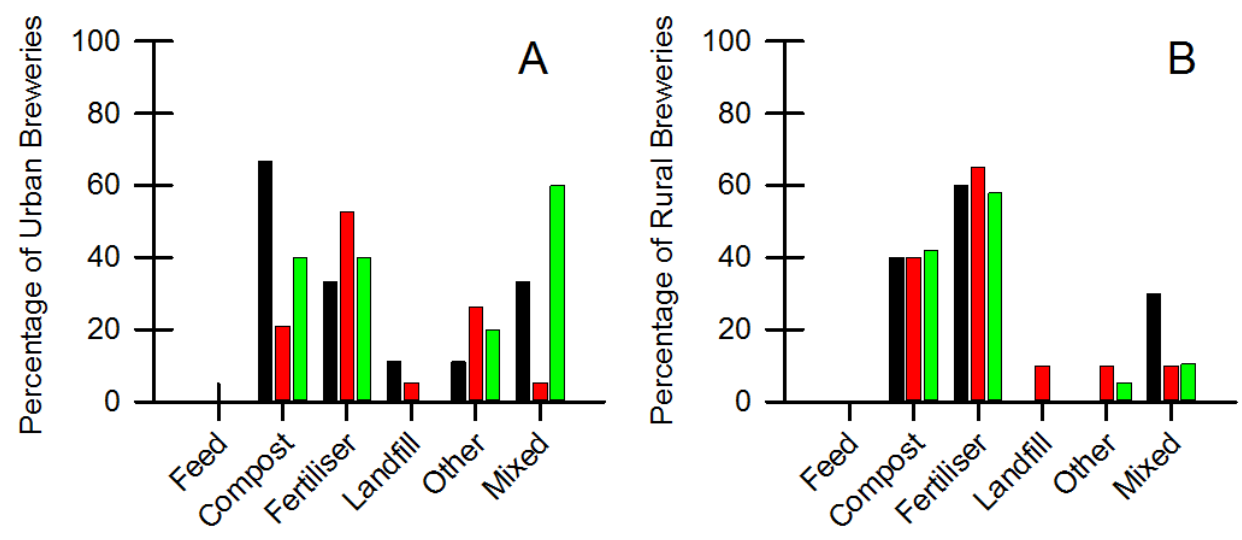

Figure 5. Spent hops disposal method in urban and rural based craft breweries. (A) Urban-based craft brewers; (B) rural-based craft breweries. Black bars: breweries with a batch capacity smaller than 1000 L; Red bars: breweries with a batch capacity greater than 1000 L, but smaller than 2000 L; Green bars: breweries with a batch capacity greater than $2000 \mathrm{~L}$. Total figures might add up to over $100 \%$ because some breweries employ multiple methods of disposal.

Spent hops/trub is probably the least voluminous of the principal brewery waste products considered here and can be stored for some time. The small, urban craft breweries tend to have their spent hops removed once a week, compared to their medium-sized and large craft brewing urban colleagues who accumulate their spent hops faster and tend to dispose of the spent hops 2-3 times a week (Table 3). The rural craft brewers dispose of their spent hops/trub in a somewhat more ad-hoc 
manner with a large proportion having the ability to dispose of their spent hops once a week. The vast majority of craft brewers do not incur any costs with regards to the disposal of their spent hops. However, in some instances the brewers either contribute to the cost of spent hops/trub disposal or incur all costs. Very few craft brewers receive payment for their spent hops/trub.

Table 3. Frequency of spent hops removal and costs incurred, by brewery location and size.

\begin{tabular}{ccccccccc}
\hline \multirow{2}{*}{$\begin{array}{c}\text { Brewery: } \\
\begin{array}{c}\text { Location \& } \\
\text { Size }\end{array}\end{array}$} & \multicolumn{3}{c}{$\begin{array}{c}\text { Frequency of Spent Hops Removal from } \\
\text { Brewery Site }\end{array}$} & \multicolumn{3}{c}{$\begin{array}{c}\text { Cost Involved in Removal of Spent Hops } \\
\text { from Brewery Site }\end{array}$} \\
\cline { 2 - 9 } & Daily & 2-3/Week & Weekly & $\begin{array}{c}\text { When } \\
\text { Required }\end{array}$ & $\begin{array}{c}\text { Brewery } \\
\text { Incurs } \\
\text { No Cost }\end{array}$ & $\begin{array}{c}\text { Brewery } \\
\text { Facilitates } \\
\text { Disposal }\end{array}$ & $\begin{array}{c}\text { Brewery } \\
\text { Incurs } \\
\text { All Costs }\end{array}$ & $\begin{array}{c}\text { Brewery } \\
\text { Receives } \\
\text { Payment }\end{array}$ \\
\hline Urban-S & $0.0 \%$ & $11.1 \%$ & $77.8 \%$ & $11.1 \%$ & $55.6 \%$ & $22.2 \%$ & $11.1 \%$ & $11.1 \%$ \\
Urban-M & $15.8 \%$ & $47.4 \%$ & $21.1 \%$ & $15.8 \%$ & $68.4 \%$ & $10.5 \%$ & $21.1 \%$ & $0.0 \%$ \\
Urban-L & $16.7 \%$ & $66.7 \%$ & $8.3 \%$ & $8.3 \%$ & $75.0 \%$ & $0.0 \%$ & $16.7 \%$ & $8.3 \%$ \\
Rural-S & $40.0 \%$ & $20.0 \%$ & $30.0 \%$ & $10.0 \%$ & $80.0 \%$ & $20.0 \%$ & $0.0 \%$ & $0.0 \%$ \\
Rural-M & $30.0 \%$ & $20.0 \%$ & $50.0 \%$ & $0.0 \%$ & $90.0 \%$ & $5.0 \%$ & $5.0 \%$ & $0.0 \%$ \\
Rural-L & $10.5 \%$ & $21.1 \%$ & $36.8 \%$ & $31.6 \%$ & $63.2 \%$ & $15.8 \%$ & $15.8 \%$ & $5.2 \%$ \\
\hline
\end{tabular}

The representative from a large rural craft brewery (Brewery RL5) was also interviewed with regards to their method of spent hops disposal. The hops are disposed of at the same farm that utilizes their spent grain. However, instead of being used as animal feed, the spent hops are "used by the farmer as a great soil improver, allowing the soil to retain more moisture" (quote: brewer RL5, 2017). The large rural brewery produces a large volume of spent hops and from time to time pay for a digger to be hired to help the farmer dig the spent hops into the soil.

The brewer from a small, urban brewery (US9) stated that all their spent grain, yeast and hops are removed from their site for use in an anaerobic digester. The brewer went on to say: "I use the biogas, as it is eco-friendly", and "secondly it allows me to dispose of grain, hops and yeast etc. in the same containers". "This nice and efficient with regards to one pick-up, one relationship, and one invoice. It is a contractual relationship between two limited companies, I pay a deposit for the bins and then a collection fee when I request a pickup." The brewer went on to indicate how the relationship started and said: "It is reasonably priced, and I needed disposal that week and they could get setup quickly. I had their number from a fellow brewer who was impressed with their reliability. Some farmers are not as reliable and can leave you with $500 \mathrm{~kg}$ of rotting grain. This way just works." (quote: brewer US9, 2017)

Another urban brewery (UM10) was also interviewed with a principal discussion point being their spent hop and spent yeast disposal method. They dispose of both through a bio-recycling company for large-scale organic material composting. The relationship was established by the brewery through contacting the company after researching food waste collection companies within their urban area. This medium-sized urban brewery chose this disposal method mainly because "this method specifically benefits the environment" (quote: brewer UM10, 2017).

\section{Discussion}

The results from this study indicate that craft brewers will utilise similar means of disposing of their by-products as their large industrial counterparts [2]. However, these routes of disposal are affected by limitations due to the size and location of the brewing operations, which influence the availability and applicability of options. When comparing the British urban- and rurally-located craft breweries, a larger proportion of rural breweries incur no cost for the disposal of their by-products compared to breweries in an urban location. The rural located breweries remove their by-product more frequently than urban breweries and this could be because breweries who dispose of their by-products via a farm indicated that the farm's location was closer to the brewery making disposal easier. Regardless of their location, only $18 \%$ of the large craft breweries remove their waste weekly, 
the remainder of the large craft breweries remove their by-products much more frequently. Compared to the large craft breweries, weekly removal of brewery by-products my medium-sized and small craft brewers occurs at $28.7 \%$ and $36.7 \%$, respectively.

The interviews within this study revealed that all British craft breweries whose by-products were used for either the feed or food purposes had a dedicated EC:183/2005-HACCP system in place, but were not necessarily part of an assurance scheme. Similarly, the interviews also showed that if by-products did not go into the food/feed chain then there is no need for a dedicated EC:183/2005-HACCP plan or an assurance scheme to be in place. However; many of the craft breweries interviewed considered this as good practice and had so use a dedicated EC:183/2005 HACCP plan regardless.

Comparing the results for urban and rural located breweries the main findings were that rurally-located breweries principally dispose of their spent grain as animal feed, whereas urban breweries explored a much wider range of disposal methods. Animal feed as a prime route for spent grain disposal among the craft brewers mirrors the practices of the very large industrial breweries [2,28]. However, the craft brewers dealt with the users of the spent grain directly and rarely utilised a contracted third party company to facilitate the removal of their spent grains. Many of the British craft brewers have capitalised on these perceived short comings and turned potentially impossible odds into their favour. A prime example was the large rural brewery (RL5) who capitalised on the 'local' concept by collaborating with a local pig farmer, whose pigs are fed the brewer's spent grain and whose meat is served in the brewery's tap house.

For the disposal of spent yeast, the rural breweries explore a wider range of disposal methods and for hop/trub disposal urban breweries show a larger variation in disposal methods. From a cost perspective, a larger proportion of rural breweries incur no cost for the disposal of their by-products, whilst urban breweries are more likely to incur the cost of transporting their by-products to their disposal location; $17.5 \%$ of urban breweries, compared to $10.7 \%$ of rural breweries, incur transport costs. Rural breweries remove their by-product more frequently than urban breweries. This could be because breweries who dispose of their by-products via a farm indicated that the farm's location is closer to the brewery making disposal easier.

Comparing craft breweries of different sizes (small, medium, large), the main findings were that smaller craft brewers opt to use sewage and landfill disposal methods, possibly because of the small volume of by-products which they produce.

In conclusion, this report has demonstrated that craft brewers explore various unique and sustainable methods of by-product disposal to benefit both the environment and their breweries' economic output.

Author Contributions: C.K and F.V. conceived and designed the questionnaire and interview approach; C.K. facilitated the interviews; C.K. and F.V analysed the data; and both C.K. and F.V. contributed to writing the paper.

Conflicts of Interest: The authors declare no conflict of interest.

\section{References}

1. Dos Santos Mathias, T.R.; de Mello, P.P.M.; Servulo, E.F.C. Solid wastes in brewing process: A review. J. Brew. Distill. 2014, 5, 1-9.

2. Huige, N. Brewery by-products and effluents. In Handbook of Brewing, 2nd ed.; Priest, F.G., Stewart, G.G., Eds.; Taylor \& Francis Group: Boca Raton, FL, USA, 2006; pp. 656-707.

3. Murray, D.W.; O’Neill, M.A. Craft beer: Penetrating a niche market. Br. Food J. 2012, 114, 899-909. [CrossRef]

4. Brewers Association (2017) Craft Brewer Defined. Available online: https://www.brewersassociation.org/ statistics/craft-brewer-defined/ (accessed on 31 May 2017).

5. Mussatto, S.I. Brewer's spent grain: A valuable feedstock for industrial applications. J. Sci. Food Agric. 2014, 94, 1264-1275. [CrossRef] [PubMed]

6. Fărcaş, A.; Tofană, M.; Socaci, S.; Mudura, E.; Scrob, S.; Salanţă, L.; Mureşan, V. Brewers' spent grain-A new potential ingredient for functional foods. J. Agroaliment. Proc. Technol. 2014, 20, 137-141. 
7. Thomas, K.R.; Rahman, P.K.S.M. Brewery wastes. Strategies for sustainability. A review. Asp. Appl. Biol. 2006, 80, 147-153.

8. Stocks, C.; Barker, A.J.; Guy, S. The composting of brewery sludge. J. Inst. Brew. 2002, 108, 452-458. [CrossRef]

9. Keller-Reinspach, H.W. Emissions during the combustion of spent brewer's grains. Brauwelt 1989, 129, 2316-2319.

10. Deublein, D.; Steinhauser, A. Biogas from Waste and Renewable Resources: An Introduction; John Wiley \& Sons: Weinheim, Germany, 2011.

11. O'Rourke, T. Making the most of your hops. New Brewer. 1994, 11, $20-33$.

12. Bedini, S.; Flamini, G.; Girardi, J.; Cosci, F.; Conti, B. Not just for beer: Evaluation of spent hops (Humulus lupulus L.) as a source of eco-friendly repellents for insect pests of stored foods. J. Pest Sci. 2015, 88, 583-592. [CrossRef]

13. Djuragic, O.; Levic, J.; Serdanovic, S. Use of new feed from brewery by-products for breeding layers. Romanian Biotechnol. Lett. 2010, 15, 5559-5565.

14. Aliyu, S.; Bala, M. Brewer's spent grain: A review of its potentials and applications. Afr. J. Biotechnol. 2011, 10, 324-331.

15. Ben-Hamed, U.; Seddighi, H.; Thomas, K. Economic returns of using brewery's spent grain in animal feed. World Acad. Sci. Eng. Technol. 2011, 50, 695-698.

16. Newbold, C.J.; Wallace, R.J.; McIntosh, F.M. Mode of action of the yeast Saccharomyces cerevisiae as a feed additive for ruminants. Br. J. Nutr. 1996, 76, 249-261. [CrossRef] [PubMed]

17. Cheung, L. Feed Additives for Pigs. U.S. Patent Application No. 10/175,054, 18 June 2002.

18. Ferreira, I.M.P.L.V.O.; Pinho, O.; Vieira, E.; Tavarela, J.G. Brewer's Saccharomyces yeast biomass: Characteristics and potential applications. Trends Food Sci. Technol. 2010, 21, 77-84. [CrossRef]

19. Munch, P.; Hofmann, T.; Schieberle, P. Comparison of key odorants generated by thermal treatment of commercial and self-prepared yeast extracts: Influence of the amino acid composition on odorant formation. J. Agric. Food Chem. 1997, 45, 1338-1344. [CrossRef]

20. Sombutyanuchit, P.; Suphantharika, M.; Verduyn, C. Preparation of 5'-GMP-rich yeast extracts from spent brewer's yeast. World J. Microbiol. Biotechnol. 2001, 17, 163-168. [CrossRef]

21. Vieira, E.F.; Carvalho, J.; Pinto, E.; Cunha, S.; Almeida, A.A.; Ferreira, I.M. Nutritive value, antioxidant activity and phenolic compounds profile of brewer's spent yeast extract. J. Food Compos. Anal. 2016, 52, 44-51. [CrossRef]

22. Food Standards Agency. Feed Hygiene Regulation (183/2005): How to Apply for Approval or Registration, and Related Information. 2013. Available online: https:/ /www.food.gov.uk/businessindustry/ farmingfood/animalfeed/animalfeedlegislation/approvregfeedguidance (accessed on 31 May 2017).

23. BFBI. BFBI Feed Assurance Scheme. 2016. Available online: http://www.bfbi.org.uk/training/bfbi-feedassurance-scheme (accessed on 31 May 2017).

24. Henderson, N. Silage additives. Anim. Feed Sci. Technol. 1993, 4, 35-56. [CrossRef]

25. Murphy \& Sons. Ammonium Tetraformate Solution-Spent Grain Treatment. 2015. Available online: http://blog.murphyandson.co.uk/category/spent-grain-treatment/ (accessed on 31 May 2017).

26. Conaghan, P.; O'Kiely, P.; O'Mara, F.P. Conservation characteristics of wilted perennial ryegrass silage made using biological or chemical additives. J. Dairy Sci. 2010, 93, 628-643. [CrossRef] [PubMed]

27. Brito, A.F.; Broderick, G.A.; Colmenero, J.O.; Reynal, S.M. Effects of feeding formate-treated alfalfa silage or red clover silage on omasal nutrient flow and microbial protein synthesis in lactating dairy cows. J. Dairy Sci. 2007, 90, 1392-1404. [CrossRef]

28. Lynch, K.M.; Steffen, E.J.; Arendt, E.K. Brewers' spent grain: A review with an emphasis on food and health. J. Inst. Brew. 2016, 122, 553-568. [CrossRef]

29. Mussatto, S.I. Biotechnological potential of brewing industry by-products. In Biotechnology for Agro-Industrial Residues Utilisation; Singh-Nee Nigam, P., Pandey, A., Eds.; Springer: Dordrecht, The Netherlands, 2009; pp. 313-326.

(C) 2017 by the authors. Licensee MDPI, Basel, Switzerland. This article is an open access article distributed under the terms and conditions of the Creative Commons Attribution (CC BY) license (http:/ / creativecommons.org/licenses/by/4.0/). 